\section{Fabiana Maluf Rabacow' \\ Olinda do Carmo Luiz"}

Ana Maria Malik"I,II

Alex Burdorfiv

Programa de Pós-Graduação em Medicina Preventiva. Faculdade de Medicina. Universidade de São Paulo. São Paulo, SP Brasil

Departamento de Medicina Preventiva. Faculdade de Medicina. Universidade de São Paulo. São Paulo, SP, Brasil

III Departamento de Administração e Recursos Humanos. Escola de Administração de Empresas de São Paulo, Faculdade Getulio Vargas. São Paulo, SP, Brasil

Department of Public Health. Erasmus MC University Medical Center. Rotterdam, The Netherlands

\section{Correspondence:}

Fabiana Maluf Rabacow

Departamento de Medicina Preventiva - USP

Av. Dr. Arnaldo, $4552^{\circ}$ andar

01246-903 São Paulo, SP, Brasil

E-mail: fabianamr@usp.br

\title{
Lifestyle factors, direct and indirect costs for a Brazilian airline company
}

\section{Fatores de estilo de vida, gastos diretos e indiretos por companhia aérea brasileira}

\begin{abstract}
OBJECTIVE: To analyze lifestyle risk factors related to direct healthcare costs and the indirect costs due to sick leave among workers of an airline company in Brazil.

METHODS: In this longitudinal 12-month study of 2,201 employees of a Brazilian airline company, the costs of sick leave and healthcare were the primary outcomes of interest. Information on the independent variables, such as gender, age, educational level, type of work, stress, and lifestyle-related factors (body mass index, physical activity, and smoking), was collected using a questionnaire on enrolment in the study. Data on sick leave days were available from the company register, and data on healthcare costs were obtained from insurance records. Multivariate linear regression analysis was used to investigate the association between direct and indirect healthcare costs with sociodemographic, work, and lifestyle-related factors.
\end{abstract}

RESULTS: Over the 12-month study period, the average direct healthcare expenditure per worker was US\$505.00 and the average indirect cost because of sick leave was US $\$ 249.00$ per worker. Direct costs were more than twice the indirect costs and both were higher in women. Body mass index was a determinant of direct costs and smoking was a determinant of indirect costs.

CONCLUSIONS: Obesity and smoking among workers in a Brazilian airline company were associated with increased health costs. Therefore, promoting a healthy diet, physical activity, and anti-tobacco campaigns are important targets for health promotion in this study population.

DESCRIPTORS: Aviation, manpower. Absenteeism. Life Style. Occupational Health. Health Expenditures. Cohort Studies. 


\section{RESUMO}

OBJETIVO: Analisar fatores de estilo de vida relacionados aos gastos diretos com saúde e indiretos com absenteísmo de trabalhadores de companhia aérea brasileira.

MÉTODOS: Coorte retrospectiva com 2.201 trabalhadores de uma companhia área de São Paulo, SP, em 2010. Os desfechos de interesse foram: gastos com serviços de saúde e com ausência no trabalho. As variáveis independentes sexo, idade, nível educacional, tipo de trabalho, estresse e fatores relacionados ao estilo de vida (índice de massa corporal, atividade física e tabagismo) foram obtidas por entrevista. Informações sobre absenteísmo foram obtidas dos registros da companhia aérea e dados sobre serviços de saúde foram informados pela operadora de saúde responsável pelo plano de saúde dos funcionários da empresa. Foi realizada regressão linear múltipla para analisar a associação entre as variáveis.

RESULTADOS: A média de gastos por trabalhador foi de US $\$ 505,00$ com serviços de saúde e US $\$ 249,00$ devido ao absenteísmo nos 12 meses de seguimento. Gastos diretos foram superiores aos gastos indiretos e ambos foram maiores em mulheres. Índice de massa corporal e tabagismo associaram-se a gastos diretos e indiretos, respectivamente.

CONCLUSÕES: Excesso de peso e tabagismo significaram maiores gastos dentro de um ano, o que sugere que dieta saudável, atividade física e controle do tabagismo são importantes alvos em programas de promoção da saúde para a população estudada.

DESCRITORES: Aviação, recursos humanos. Absenteísmo. Estilo de Vida. Saúde do Trabalhador. Gastos em Saúde. Estudos de Coortes.

\section{INTRODUCTION}

The economic burden of non-communicable diseases has been a reason of concern worldwide. Modifiable risk factors, such as obesity, physical inactivity, and smoking, are among the top five contributors to these diseases..$^{18}$ Efforts by companies to understand how these risk factors affect the health and productivity of employees have been economically justified.

In 1991, Bertera ${ }^{3}$ quantified healthcare costs using medical claims data and the evaluation of risk factors. Since then, there is a better understanding of the relationship between lifestyle risk factors and health expenses and productivity. The original Health Enhancement Research Organization study concluded that workers at high risk had significantly higher expenses associated with seven of the ten modifiable risk factors studied. ${ }^{8}$ Several studies have supported the association between positive changes in lifestyle and reduced expenditure on health services, strengthening the importance of investment in strategies to promote healthy habits. ${ }^{5,16,18,23}$ Expenditure associated with health risks increases when indirect costs, such as absenteeism, which has also been associated with modifiable risk factors, are considered. ${ }^{13,14,21,25}$

Effective interventions have a significant economic benefit. A meta-analysis of 22 studies concluded that health promotion programs in the workplace had an average investment return of US\$3.27 for medical costs and US $\$ 2.73$ for absenteeism. ${ }^{2}$ However, the studies included in the meta-analysis were conducted in developed countries. The distribution and determinants of direct and indirect costs with health are not well understood in countries with emerging economies, like Brazil, where the burden of non-communicable diseases is high. ${ }^{22}$ Furthermore, characteristics of work and the workplace, healthcare system, and lifestyle differ between developed and developing countries. Therefore, studies in developing nations are necessary to design health promotion programs tailored for workers in this setting with greater chances of success.

This study aimed to analyze lifestyle risk factors related to direct healthcare costs and the indirect costs due to sick leave among workers of an airline company in Brazil. 


\section{METHODS}

This longitudinal one-year study analyzed data from 2,201 employees of a Brazilian airline company who volunteered to participate in a survey about health and lifestyle habits. The study was conducted in Sao Paulo, SP, Southeastern Brazil, between May and November 2010. The survey about health and lifestyle was conducted by a health insurance organization responsible for healthcare services provided to the employees of the airline. The study used data collected in the health survey, 12-month data from the sickness absence register of the airline company, and 12-month data from the healthcare costs register.

In 2012, the multinational airline company had more than 28,000 employees in Sao Paulo. In total, 3,147 employees who were present, available, and agreed to participate were evaluated. Of these, 933 outsourced employees were excluded due to insufficient data. After the exclusion of pregnant women $(n=13)$, the study population included 2,201 participants ( $16.6 \%$ of the company's Sao Paulo-based employees). All employees were covered by the same healthcare provider.

Astructured questionnaire, with questions related to health and lifestyle, was provided in an interview conducted by a team of nurses in the workplace of the participants. Weight and height were self-reported. The outcomes of interest were healthcare costs (direct costs) and sick leave costs (indirect costs). Both were analyzed for 12 months after completion of the health and lifestyle survey.

Information about healthcare costs was obtained from the insurance company. Data included the total healthcare expenditure per worker during the follow-up year as well the numbers and costs of each type of intervention: medical appointments (doctor visits), diagnostic tests, and hospitalizations (at least one day of in-hospital care due to health problems). The costs included the amount paid by the healthcare insurance company to the medical service establishments.

Information on sick leave was obtained from personnel records of the airline company. The cost of each day of sick leave was estimated based on the average nominal monthly income (US\$763.21) for Brazilian employees in the private sector in 2012. ${ }^{a}$ This value was divided by 22 days to obtain the cost for each day of sick leave (US\$34.69). ${ }^{\mathrm{b}}$ Lost productivity at work, known as presenteeism, was not considered in this study.

The lifestyle-related factors considered were body mass index (BMI), smoking (current smoker, ex-smoker, or non-smoker), and physical activity. BMI was calculated by dividing the self-reported body weight $(\mathrm{kg})$ by self-reported height squared $\left(\mathrm{m}^{2}\right)$ and was classified as normal $\left(18.5-24.9 \mathrm{~kg} / \mathrm{m}^{2}\right)$, overweight $\left(25-29.9 \mathrm{~kg} / \mathrm{m}^{2}\right)$, or obese $\left(\geq 30 \mathrm{~kg} / \mathrm{m}^{2}\right) .{ }^{27}$ Physical activity, self-reported by participants based on their level of physical activity at work and during leisure time, was categorized into the following: very little (remaining seated at work and little or no leisure-time physical activity), little (remaining seated at work and light to moderate leisuretime physical activity approximately twice a week), and regular (moderate to intense physical activity three or more times a week at work or during leisure time).

Other independent variables included sociodemographic characteristics (age, gender, and educational level), type of work (administrative, blue collar, call center, or aircrew), and stress. Stress was self-reported using a Likert scale (0: without stress; 10: the highest level of stress). This variable was classified into low stress (0-3), moderate stress (4-6), and high stress (7-10).

Descriptive analysis was used for characterizing the study population. Pearson's correlation was used to analyze the correlation between direct and indirect healthcare costs. Multiple linear regression analysis was conducted, with age and BMI as continuous variables. Further, multicollinearity analysis was conducted to test the correlation of the error terms of the independent variables. The odds ratio for one or more hospitalization by sociodemographic characteristics, type of work, and lifestyle-related factors was calculated using multinomial logistic regression analysis. All analyses were conducted using Stata 12.0.

This study was approved by the Ethics Committee in Research of the Faculdade de Medicina of Universidade de São Paulo (Process 083/12). Data collection was anonymous.

\section{RESULTS}

The mean age of the employees was 32.2 years $(\mathrm{SD}=8.4)$ and $58.0 \%$ were male; approximately $85.0 \%$ had not completed university studies. The bluecollar work sector accounted for the largest group of participants (35.0\%). Most workers (76.0\%) reported moderate or high levels of stress. Almost half of the participants were overweight or obese, approximately $80.0 \%$ reported little or very little physical activity, and $13.0 \%$ were smokers (Table 1). There were major differences in lifestyle-related factors between men and women. Men were more likely to be overweight $(\mathrm{OR}=4.02 ; 95 \% \mathrm{CI} 3.28 ; 4.92)$, obese $(\mathrm{OR}=4.65 ; 95 \% \mathrm{CI} 3.41 ; 6.34)$, or be smokers $(\mathrm{OR}=1.48 ; 95 \% \mathrm{CI} 1.13 ; 1.93)$. Women were more likely to be less physically active $(\mathrm{OR}=1.82 ; 95 \% \mathrm{CI} 1.43 ; 2.30)$.

\footnotetext{
a Instituto Brasileiro de Geografia e Estatística. Pesquisa Mensal de Emprego. Brasília (DF); 1980. Available from: http://www.ibge.gov.br/home/ estatistica/indicadores/trabalhoerendimento/pme_nova/

${ }^{\mathrm{b}}$ Conversion of Real (Brazilian currency) into U.S. dollars was performed considering the exchange rate on the date of September $9,2013,(1$ U.S. dollar $=2.297$ reais).
} 
Table 1. Baseline characteristics among workers of an airline company by sex. Sao Paulo, Southeastern Brazil, 2010 (N =2,201)

\begin{tabular}{|c|c|c|c|c|}
\hline \multirow{2}{*}{ Individual characteristic } & \multicolumn{2}{|c|}{ Female } & \multicolumn{2}{|c|}{ Male } \\
\hline & $\mathrm{n}$ & $\%$ & $\mathrm{n}$ & $\%$ \\
\hline \multicolumn{5}{|l|}{ Age (years) } \\
\hline$\leq 29$ & 531 & 57.3 & 451 & 35.4 \\
\hline 30 to 39 & 309 & 33.3 & 523 & 41.0 \\
\hline 40 to 49 & 75 & 8.1 & 213 & 16.7 \\
\hline$\geq 50$ & 12 & 1.3 & 87 & 6.8 \\
\hline \multicolumn{5}{|l|}{ Educational level } \\
\hline Elementary school & 848 & 91.5 & 790 & 62.0 \\
\hline High school & 8 & 0.9 & 160 & 12.6 \\
\hline College & 71 & 7.6 & 324 & 25.4 \\
\hline \multicolumn{5}{|l|}{ Type of work } \\
\hline Administrative jobs & 317 & 34.2 & 280 & 22.0 \\
\hline Call center & 224 & 24.2 & 100 & 7.8 \\
\hline Blue-collar jobs & 90 & 9.7 & 689 & 54.1 \\
\hline Aircrew & 296 & 31.9 & 205 & 16.1 \\
\hline \multicolumn{5}{|l|}{ Perceived stress in life } \\
\hline Low & 164 & 17.7 & 341 & 26.8 \\
\hline Moderate & 343 & 37.2 & 486 & 38.3 \\
\hline High & 417 & 45.1 & 443 & 34.9 \\
\hline \multicolumn{5}{|l|}{ Lifestyle-related factors } \\
\hline \multicolumn{5}{|l|}{ Body mass index } \\
\hline Normal weight $(18.5 ; 24.9)$ & 632 & 71.7 & 480 & 37.8 \\
\hline Overweight $(25.0 ; 29.9)$ & 189 & 21.4 & 577 & 45.5 \\
\hline Obesity ( $\geq 30$ ) & 60 & 6.8 & 212 & 16.7 \\
\hline \multicolumn{5}{|l|}{ Physical activity level } \\
\hline Regular & 134 & 14.4 & 282 & 22.1 \\
\hline Little & 187 & 20.2 & 319 & 25.0 \\
\hline Very little & 606 & 65.4 & 673 & 52.8 \\
\hline \multicolumn{5}{|l|}{ Smoking } \\
\hline Non smoker & 731 & 78.9 & 931 & 73.1 \\
\hline Ex-smoker & 102 & 11.0 & 166 & 13.0 \\
\hline Smoker & 94 & 10.1 & 177 & 13.9 \\
\hline
\end{tabular}

Approximately $72.0 \%$ of employees had at least one medical appointment, $84.0 \%$ underwent at least one diagnostic test, and $6.0 \%$ were hospitalized at least once during the 12-month follow-up. The average expenditure per worker was US\$57.00 for medical appointments, US $\$ 228.00$ for diagnostic tests, and US\$162.00 for hospitalizations. The maximum medical expenditure per worker in one year was US $\$ 24.00$, the maximum expenditure on diagnostics tests was US $\$ 150.00$, and the maximum expenditure of hospitalization was US\$15.00.

In total, US $\$ 986,343.30$ was spent on healthcare services, at an average of US $\$ 505.00$ per employee.
Approximately $10.0 \%$ of workers accounted for more than $90.0 \%$ of healthcare expenditure and this number was even stronger for expenditure related to hospitalizations. Diagnostic tests accounted for half of the healthcare expenditure, approximately one third was spent on hospitalizations, and $13.0 \%$ on medical appointments.

Women had more medical appointments and diagnostic tests than men. Elderly employees had more medical appointments, diagnostic tests, and hospitalizations than younger workers, and the costs involved with each were higher for the elderly employees. No differences were found in medical interventions among different educational levels (Table 2).

More than half of the employees (53.0\%) had at least one sick leave episode during the 12-month followup, with an average indirect cost of US\$249.00 per employee. The maximum number of sick leave was 87 days. Sick leave episodes were more frequent in women, in young employees, and in participants with lower education levels (Table 3 ).

Sick leave expenditure (indirect costs) was correlated with healthcare expenditure (direct costs), but the correlation was modest (Pearson's correlation coefficient $=0.21$; Figure $)$.

On average, compared with men, direct costs for women were US $\$ 180.00$ higher and indirect costs were US $\$ 40.00$ higher during the 12-month follow-up. Compared with employees in the administrative sector, average direct costs for blue-collar workers were US $\$ 177.00$ lower, while average indirect costs for aircrew were US $\$ 45.00$ higher compared with employees in the administrative sector. Moreover, of lifestyle-related factors, each increased unit of BMI raised direct costs by an average of US\$17.00 over the 12-month follow-up. However, BMI was not associated with indirect costs. For these analyses, 51 underweight $\left(B M I<18.5 \mathrm{~kg} / \mathrm{m}^{2}\right.$ ) participants were excluded. Smoking was not associated with direct costs but with indirect costs. On average, indirect costs for current smokers and ex-smokers were US $\$ 44.00$ and US\$37.00 higher, respectively, compared with non-smokers. Physical activity was not associated with the total cost of medical interventions, but it was associated with the odds of hospitalization. Employees with little physical activity had almost twice the odds of at least one episode of hospitalization $(\mathrm{OR}=1.96 ; 95 \% \mathrm{CI} 1.05 ; 3.65)$ as did those with very little physical activity $(\mathrm{OR}=1.94 ;$ 95\%CI 1.09;3.43) (Table 4).

\section{DISCUSSION}

Over the 12-month study period, the average direct healthcare cost per worker was US\$505.00 and the 
Table 2. Descriptive statistics of health interventions by sociodemographic characteristics. Sao Paulo, SP, Southeastern Brazil, 2010.

\begin{tabular}{|c|c|c|c|c|c|c|c|c|c|c|c|c|}
\hline \multirow{3}{*}{$\begin{array}{l}\text { Sociodemographic } \\
\text { characteristic }\end{array}$} & \multicolumn{4}{|c|}{ Medical appointment } & \multicolumn{4}{|c|}{ Diagnostic test } & \multicolumn{4}{|c|}{ Hospitalization $(\geq 1)$} \\
\hline & \multicolumn{2}{|c|}{ Amount } & \multicolumn{2}{|c|}{ Costs $\$$} & \multicolumn{2}{|c|}{ Amount } & \multicolumn{2}{|c|}{ Costs $\$$} & \multicolumn{2}{|c|}{ Amount } & \multicolumn{2}{|c|}{ Costs $\$$} \\
\hline & Mean & Q1;Q3 & Mean & Q1;Q3 & Mean & Q1;Q3 & Mean & Q1;Q3 & Mean & Q1;Q3 & Mean & Q1;Q3 \\
\hline \multicolumn{13}{|l|}{ Gender } \\
\hline Male & 2.0 & $0 ; 3$ & 42 & $0 ; 59$ & 11 & $1 ; 15$ & 195 & $19 ; 224$ & 0.23 & $0 ; 0$ & 138 & $0 ; 0$ \\
\hline Female & 4.1 & $1 ; 6$ & 79 & $19 ; 114$ & 19 & $4 ; 28$ & 273 & $67 ; 383$ & 0.26 & $0 ; 0$ & 196 & $0 ; 0$ \\
\hline \multicolumn{13}{|l|}{ Age (years) } \\
\hline$\leq 24$ & 2.9 & $0 ; 4$ & 56 & $0 ; 83$ & 14 & $2 ; 20$ & 233 & $36 ; 289$ & 0.23 & $0 ; 0$ & 164 & $0 ; 0$ \\
\hline 25 to 34 & 2.8 & $0 ; 4$ & 56 & $0 ; 87$ & 14 & $1 ; 21$ & 221 & $29 ; 287$ & 0.26 & $0 ; 0$ & 179 & $0 ; 0$ \\
\hline 35 to 44 & 2.9 & $0 ; 4$ & 60 & $0 ; 88$ & 15 & $2 ; 22$ & 213 & $37 ; 299$ & 0.23 & $0 ; 0$ & 111 & $0 ; 0$ \\
\hline$\geq 45$ & 3.4 & $1 ; 5$ & 72 & $17 ; 108$ & 18 & $1 ; 32$ & 225 & $26 ; 339$ & 0.35 & $0 ; 0$ & 148 & $0 ; 0$ \\
\hline \multicolumn{13}{|l|}{ Education } \\
\hline Elementary school & 2.6 & $0 ; 4$ & 54 & $0 ; 78$ & 14 & $1 ; 21$ & 211 & $28 ; 292$ & 0.31 & $0 ; 0$ & 176 & $0 ; 0$ \\
\hline High school & 2.9 & $0 ; 4$ & 58 & $0 ; 87$ & 14 & $2 ; 21$ & 234 & $34 ; 296$ & 0.23 & $0 ; 0$ & 168 & $0 ; 0$ \\
\hline College & 2.8 & $0 ; 4.5$ & 60 & $0 ; 96$ & 15 & $2 ; 21$ & 214 & $30 ; 278$ & 0.23 & $0 ; 0$ & 76 & $0 ; 0$ \\
\hline Total & 2.9 & $0 ; 4$ & 57 & $0 ; 87$ & 14 & $2 ; 21$ & 228 & $33 ; 294$ & 0.24 & $0 ; 0$ & 162 & $0 ; 0$ \\
\hline
\end{tabular}

Table 3. Descriptive statistics of sick leave by sociodemographic characteristics. Sao Paulo, SP, Southeastern Brazil, 2010.

\begin{tabular}{|c|c|c|c|c|}
\hline \multirow{3}{*}{$\begin{array}{l}\text { Sociodemographic } \\
\text { characteristic }\end{array}$} & \multicolumn{4}{|c|}{ Sick leave } \\
\hline & \multicolumn{2}{|c|}{ Amount } & \multicolumn{2}{|c|}{ Cost $\$$} \\
\hline & Mean & Q1;Q3 & Mean & Q1;Q3 \\
\hline \multicolumn{5}{|l|}{ Gender } \\
\hline Male & 3.6 & $0 ; 5$ & 126 & $0 ; 173$ \\
\hline Female & 5.6 & $0 ; 8$ & 193 & $0 ; 277$ \\
\hline \multicolumn{5}{|l|}{ Age (years) } \\
\hline$\leq 24$ & 4.9 & $0 ; 7$ & 173 & $0 ; 243$ \\
\hline 25 to 34 & 4.2 & $0 ; 6$ & 146 & $0 ; 208$ \\
\hline 35 to 44 & 3.8 & $0 ; 6$ & 132 & $0 ; 208$ \\
\hline$\geq 45$ & 3.2 & $0 ; 4$ & 110 & $0 ; 139$ \\
\hline \multicolumn{5}{|l|}{ Education } \\
\hline Elementary school & 4.7 & $0 ; 7$ & 164 & $0 ; 243$ \\
\hline High school & 3.3 & $0 ; 5$ & 115 & $0 ; 173$ \\
\hline College & 3.8 & $0 ; 5$ & 132 & $0 ; 173$ \\
\hline Total & 4.4 & $0 ; 6$ & 154 & $0 ; 208$ \\
\hline
\end{tabular}

average indirect cost due to sick leave was US\$249.00 per worker. Direct costs were more than twice the indirect costs and both were higher in women. BMI was a determinant of direct costs and smoking was a determinant of indirect costs. Physical activity was not associated with total direct or indirect costs, but it was associated with the odds of hospitalization.

Several studies conducted in developed countries show that indirect costs accounted for the largest proportion of total healthcare expenditures. ${ }^{6,9,11}$ However, the direct costs were more than twice the indirect costs in the present study. Two factors may explain this finding.

First, the calculation of the cost of sick leave based on salary represents only a small proportion of the real indirect costs. Loss in productivity associated with the absence of employees and the taxes paid by the company per employee were not considered in the present study (in Brazil, taxes account for $36.8 \%$ of the salary). Presenteeism was also not considered and it is known to account for a considerable proportion of the indirect costs of healthcare. ${ }^{9}$

Second, the average wage in Brazil is lower than that in the developed countries. In an American study, each absence day was multiplied by US $\$ 240.00$ to estimate the value of a sick leave day, reflecting the average wages paid to employees of large American companies..$^{10}$ In the present study, one day of sick leave was estimated at US\$34.69.

The historical development of the current Brazilian healthcare system has several unique features. The 1988 Brazilian Constitution mentions health and defines the Brazilian Unified Health System (SUS), which establishes health as a right of the citizens, to be assured by the State. Universal coverage, equity, and integral care are among the SUS principles. However, all care is not provided or financed by the public sector; therefore, SUS is a single system with two subsystems, public and private. In the $1990 \mathrm{~s}$, the $8,080 \mathrm{Law}$ stated that the private sector could exist and in 1998, the 9,656 Law was established, designing a regulatory system for private acts. Further, the National Agency for Supplementary Health, responsible for this regulation, was created. In 2008, approximately $26.0 \%$ of Brazil's 


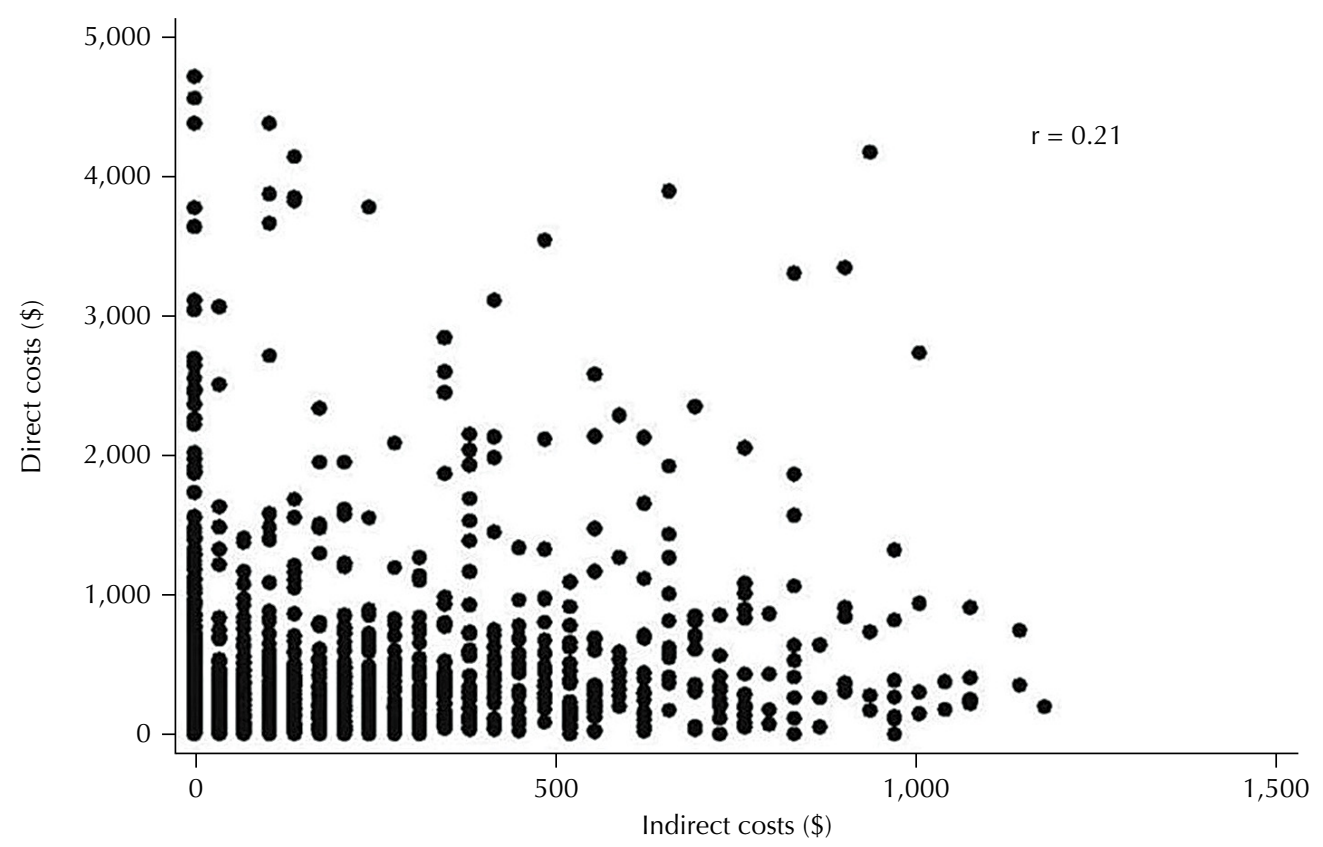

Figure. Association between healthcare expenditure (direct costs) and sick leave days (indirect costs), in US dollars. Values above $99^{\text {th }}$ percentiles were excluded. Sao Paulo, SP, Southeastern Brazil, 2010.

population had private health coverage ${ }^{c}$ supplied by third-party providers (e.g., insurance companies, health maintenance organizations).

The present study population is a part of the smaller sample of the Brazilian population that has health insurance. Access to health insurance results in some differences with respect to the use of healthcare services. People with private health plans or insurance policies report having better access to preventive services and higher healthcare use rates than those who can only afford to use public services. ${ }^{.}$Because of this easier access to healthcare, in the present study, some medical appointments and diagnostic tests may have been for preventative reasons, rather than being disease related. This is a possible confounder that we were unable to control.

Studies on the determinants of direct and indirect health costs have been conducted among European and American workers. Although a number of Brazilian studies have investigated sick leave in different jobs, ${ }^{20,24}$ no study has been conducted with employees of an airline company and only two cross-sectional studies of Brazilian workers have investigated determinants of health and sick leave associated with lifestyle. ${ }^{6,7}$

Similar to the findings of the present study, in other studies $^{8,13}$ women had higher direct and indirect health costs. The gender difference in sick leave was explored in more detail in another study. ${ }^{19} \mathrm{~A}$ significant difference in lifestyle between genders did not explain the increased absenteeism among women. Furthermore, the association between gender and sick leave was explained, in part, by the type of work (15.0\%) and by educational level $(7.0 \%)$. We believe that the gender difference in direct costs partly occurred because women use health services more for preventive reasons than men. However, the information collected in the present study did not allow an investigation of this distinction in the use of health services.

Approximately $85.0 \%$ of the employees had not completed university studies, which is similar to the educational level of the population of Sao Paulo state. ${ }^{\mathrm{d}}$ Blue-collar workers, who were predominantly men $(88.0 \%)$, had lower direct costs, even after adjustment for sex. Aircrew had higher indirect costs. This type of work have some special characteristics that should be considered. For exemple, they are required to have a good physical condition. The level of physical activity of aircrew in the present study was higher compared with that of other workers. The reason for the high number of sick leave days among aircrew may depend on factors that were not examined.

Increased BMI has been associated with higher direct ${ }^{12,18}$ and indirect health costs. ${ }^{13}$ However, we only found this association for direct costs. As found in an American study, ${ }^{13}$ smoking was not associated with

c Ministério da Saúde. Agência Nacional de Saúde Suplementar. Caderno de Informação da Saúde Suplementar: beneficiários, operadoras e planos. Brasília (DF); 2009. Available from: http://www.ans.gov.br/portal/upload/informacoesss/caderno_informaca_03_2009.pdf

${ }^{\mathrm{d}}$ Instituto Brasileiro de Geografi a e Estatística. Microdados PNAD. Rio de Janeiro (RJ); 2008. 
Table 4. Multiple linear regression for direct and indirect costs among workers of an airline company. Sao Paulo, SP, Southeastern Brazil, 2010. $(\mathrm{N}=2,150)$

\begin{tabular}{|c|c|c|c|c|}
\hline \multirow{2}{*}{ Individual characteristics } & \multicolumn{2}{|c|}{ Direct costs (US\$) } & \multicolumn{2}{|c|}{ Indirect costs (US\$) } \\
\hline & $\beta$ & SE & $\beta$ & SE \\
\hline \multicolumn{5}{|l|}{ Gender } \\
\hline Male & 1.00 & & 1.00 & \\
\hline Female & $180^{\mathrm{a}}$ & 76.25 & $40^{\mathrm{a}}$ & 13.79 \\
\hline Age (years) & 3 & 4.54 & -1 & 0.82 \\
\hline \multicolumn{5}{|l|}{ Educational level } \\
\hline College & 1.00 & & 1.00 & \\
\hline High school & 14 & 88.92 & 2 & 16.08 \\
\hline Elementary school & -30 & 143.82 & 2 & 26.01 \\
\hline \multicolumn{5}{|l|}{ Type of work } \\
\hline Administrative & 1.00 & & 1.00 & \\
\hline Call center & -1 & 99.68 & 6 & 18.02 \\
\hline Blue collar & $-177^{a}$ & 83.96 & -17 & 15.18 \\
\hline Aircrew & -121 & 88.39 & $45^{\mathrm{a}}$ & 15.98 \\
\hline \multicolumn{5}{|l|}{ Perceived stress in life } \\
\hline Low & 1.00 & & 1.00 & \\
\hline Moderate & 8 & 80.96 & 10 & 14.64 \\
\hline High & -20 & 81.43 & 26 & 14.73 \\
\hline \multicolumn{5}{|l|}{ Lifestyle-related factors } \\
\hline Body mass index & $17^{\mathrm{a}}$ & 8.26 & -0.49 & 1.49 \\
\hline \multicolumn{5}{|l|}{ Physical activity level } \\
\hline Regular & 1.00 & & 1.00 & \\
\hline Little & 21 & 95.08 & 1 & 17.19 \\
\hline Very little & -65 & 82.88 & 13 & 14.98 \\
\hline \multicolumn{5}{|l|}{ Smoking } \\
\hline Non smoking & 1.00 & & 1.00 & \\
\hline Ex-smoker & -59 & 94.73 & $37^{\mathrm{a}}$ & 17.13 \\
\hline Smoker & -118 & 95.98 & $44^{\mathrm{a}}$ & 17.36 \\
\hline
\end{tabular}

${ }^{a} p<0,005$

medical costs, but it was associated with sick leave costs in the present study. Other studies have reported an association between smoking and sick leave.,17,21,26 Previous studies have also reported an association between a history of smoking and sick leave, ${ }^{4,15,26}$ which was supported by the findings of higher indirect costs in former smokers in the present study. Besides encouraging smoking cessation, organizations also require to provide health support for former smokers.

Although more physically active employees have been reported to have fewer sick leave episodes ${ }^{17,21}$ and lower healthcare costs,,$^{13}$ in some studies this association is weak or inconsistent. ${ }^{1,7,12}$ In the present study, physical activity was not associated with total direct or indirect costs, but physically inactive workers had almost twice the odds of hospitalization. Future longitudinal studies are required to clarify this issue.
The main limitation of this study is the non-representative sample. Only employees present in the company at the time of the assessment were considered. It is possible that workers with a poor lifestyle behavior were absent from work on the assessment date. Other potential biases were related to the self-reporting of lifestyle-related factors. Although employees knew data collection was anonymous, the possible impact on their jobs may have influenced their responses - and the database, which had already been collected, with some limited information, such as stress measurement. Furthermore, presenteeism was not evaluated. This is another important measure of productivity, accounting for a large proportion of the indirect costs. It is possible that some workers with a poor lifestyle behavior were at work, but had lower productivity. As discussed above, another potential confounder is that some medical 
appointments and diagnostic tests may have been made for preventative reason rather than being for sickness.

The strengths of this study are that it incorporated registerbased data on sick leave as well as the actual healthcare expenditure. The prospective design with a relatively large sample of employees also allowed us to draw more informed conclusions with respect to causality.

\section{REFERENCES}

1. Alavinia SM, van den Berg TI, van Duivenbooden $\mathrm{C}$, Elders LA, Burdorf A. Impact of work-related factors, lifestyle, and work ability on sickness absence among Dutch construction workers. Scand I Work Environ Health. 2009;35(5):325-33. DOI:10.5271/sjweh.1340

2. Baicker K, Cutler D, Song Z. Workplace wellness programs can generate savings. Health Aff (Millwood). 2010;29(2):304-11. DOI:10.1377/hlthaff.2009.0626

3. Bertera RL. The effects of behavioral risks on absenteeism and health-care costs in the workplace. J Occup Med. 1991;33(11):1119-24. DOI:10.1097/00043764-199111000-00006

4. Christensen KB, Lund T, Labriola M, Bultmann $U$, Villadsen $E$. The impact of health behaviour on long term sickness absence: results from DWECS/DREAM. Ind Health. 2007;45(2):348-51. DOI:10.2486/indhealth.45.348

5. Dagenais S, Caro J, Haldeman S. A systematic review of low back pain cost of illness studies in the United States and internationally. Spine J. 2008;8(1):8-20. DOI:10.1016/j.spinee.2007.10.005

6. Ferreira RC, Griep RH, Fonseca MJM, Rotenberg L. Abordagem multifatorial do absenteísmo por doença em trabalhadores de enfermagem. Rev Saude Publica. 2012;46(2):259-68. DOI:10.1590/S0034-89102012005000018

7. Fonseca VR, Nobre MR, Pronk NP, Santos LA. The association between physical activity, productivity, and health care utilization among employees in Brazil. J Occup Environ Med. 2010;52(7):706-12. DOI:10.1097/JOM.0b013e3181e41cda

8. Goetzel RZ, Anderson DR, Whitmer RW, Ozminkowski RJ, Dunn RL, Wasserman J, et al. The relationship between modifiable health risks and health care expenditures. An analysis of the multiemployer HERO health risk and cost database. J Occup Environ Med. 1998;40(10):843-54. DOI:10.1097/00043764-199810000-00003

9. Goetzel RZ, Long SR, Ozminkowski RJ, Hawkins K, Wang S, Lynch W. Health, absence, disability, and presenteeism cost estimates of certain physical and mental health conditions affecting U.S. employers. J Occup Environ Med. 2004;46(4):398-412. DOI:10.1097/01.jom.0000121151.40413.bd

10. Goetzel RZ, Carls GS, Wang S, Kelly E, Mauceri $\mathrm{E}$, Columbus $\mathrm{D}$, et al. The relationship between modifiable health risk factors and medical expenditures, absenteeism, short-term disability, and presenteeism among employees at novartis.
To implement evidence-based and effective health promotion and risk reduction programs, the airline company should focus on promoting a healthy diet, physical activity, and anti-tobacco programs as well as providing health support for former smokers. Thus, the employer can achieve positive results in terms of economy and productivity, and the employees would benefit from an improved health and well-being.
J Occup Environ Med. 2009;51(4):487-99. DOI:10.1097/JOM.0b013e31819eb902

11. Goetzel RZ, Gibson TB, Short ME, Chu BC, Waddell J, Bowen J, et al. A multi-worksite analysis of the relationships among body mass index, medical utilization, and worker productivity. J Occup Environ Med. 2010;52 Suppl 1:S52-8. DOI:10.1097/JOM.0b013e3181c95b84

12. Henke RM, Carls GS, Short ME, Pei X, Wang $S$, Moley $S$, et al. The relationship between health risks and health and productivity costs among employees at Pepsi Bottling Group. J Occup Environ Med. 2010;52(5):519-27. DOI:10.1097/JOM.0b013e3181dce655

13. Kowlessar NM, Goetzel RZ, Carls GS, Tabrizi MJ, Guindon A. The relationship between 11 health risks and medical and productivity costs for a large employer. J Occup Environ Med. 2011;53(5):468-77. DOI:10.1097/JOM.0b013e31821586b8

14. Laaksonen M, Martikainen P, Rahkonen O, Lahelma E. Explanations for gender differences in sickness absence: evidence from middle-aged municipal employees from Finland. Occup Environ Med. 2008;65(5):325-30. DOI:10.1136/oem.2007.033910

15. Laaksonen M, Piha K, Martikainen P, Rahkonen $\mathrm{O}$, Lahelma E. Health-related behaviours and sickness absence from work. Occup Environ Med. 2009;66(12):840-7. DOI:10.1136/oem.2008.039248

16. Makrides L, Smith S, Allt J, Farquharson J, Szpilfogel C, Curwin S, et al. The Healthy LifeWorks Project: a pilot study of the economic analysis of a comprehensive workplace wellness program in a Canadian government department. J Occup Environ Med. 2011;53(7):799-805. DOI:10.1097/JOM.0b013e318222af67

17. Merrill RM, Aldana SG, Pope JE, Anderson DR, Coberley CR, Grossmeier JJ, et al. Self-rated job performance and absenteeism according to employee engagement, health behaviors, and physical health. J Occup Environ Med. 2013;55(1):10-8. DOI:10.1097/JOM.0b013e31827b73af

18. Moriarty JP, Branda ME, Olsen KD, Shah ND, Borah $B$ J, Wagie AE, et al. The effects of incremental costs of smoking and obesity on health care costs among adults: a 7-year longitudinal study. J Occup Environ Med. 2012;54(3):286-91. DOI:10.1097/JOM.0b013e318246f1f4

19. Rabacow FM, Levy RB, Menezes PR, Luiz OC, Malik $A M$, Burdorf $A$. The influence of lifestyle and gender on sickness absence in Brazilian workers. BMC Public Health. 2014;14(1):317. DOI:10.1186/1471-2458-14-317 
20. Reis RJ, La Rocca PF, Silveira AM, Bonilla IML, Giné AN, Martín M. Fatores relacionados ao absenteísmo por doença em profissionais de enfermagem. Rev Saude Publica. 2003;37(5):616-23 DOI:10.1590/S0034-89102003000500011

21. Robroek SJ, van den Berg TI, Plat JF, Burdorf A. The role of obesity and lifestyle behaviours in a productive workforce. Occup Environ Med. 2011;68(2):134-9. DOI:10.1136/oem.2010.055962

22. Schmidt MI, Duncan BB, Azevedo e Silva G, Menezes AM, Monteiro CA, Barreto SM, et al. Chronic noncommunicable diseases in Brazil: burden and current challenges. Lancet. 2011;377(9781):1949-61. DOI:10.1016/S0140-6736(11)60135-9

23. Sherman BW, Lynch WD. The relationship between smoking and health care, workers' compensation, and productivity costs for a large employer. J Occup Environ Med. 2013;55(8):879-84. DOI:10.1097/JOM.0b013e31829f3129
24. Simões MRL, Rocha AM, Souza C. Fatores associados ao absenteísmo-doença dos trabalhadores rurais de uma empresa florestal. Rev Latino-Am Enfermagem. 2012;20(4):718-26. DOI:10.1590/S0104-11692012000400012

25. van Amelsvoort LG, Spigt MG, Swaen GM, Kant I. Leisure time physical activity and sickness absenteeism: a prospective study. Occup Med (Lond). 2006;56(3):210-2. DOI:10.1093/occmed/kqj026

26. Weng SF, Ali S, Leonardi-Bee J. Smoking and absence from work: systematic review and meta-analysis of occupational studies. Addiction. 2013;108(2):307-19. DOI:10.1111/add.12015

27. World Health Organization. World Health Organization (WHO).Regional Office for Europe. Programmes and Projects.Nutrition and Food Securities. 2007. Geneva; 2011.

This study was supported by the Coordenação de Aperfeiçoamento de Pessoal de Nível Superior (CAPES - Process 1892/41-2 - "Sandwich PhD" scholarship) and by the Conselho Nacional de Desenvolvimento Científico e Tecnológico (CNPQ - Process 141587/2011-3 - Doctoral Grant).

Based on the doctoral thesis of FM Rabacow, intitulada: "Estilo de vida de Trabalhadores, Absenteísmo e Gastos com Serviços de Saúde", to be presented to the Programa de Pós-Graduação em Medicina Preventiva of the Faculdade de Medicina of the Universidade de São Paulo, in 2015.

The authors declare no conflict of interest. 